\title{
Existentialism and Classroom Practice
}

\author{
G. M. Malik and Rukhsana Akhter \\ * Professor, Department of Education, University of Kashmir \\ ** Research Scholar(PhD), Department of Education, University of Kashmir
}

\begin{abstract}
This paper examines existing education literature that discusses existentialism, existential pedagogy, individual freedom, identity, and search for meaning. Through effective pedagogical strategies and by acknowledging the role of teacher, existential pedagogy will engage learners and will illuminate for them the existential motivations for learning. The study revealed that every technique, every tool, every gesture is a way that opens upon the world, therefore existentialist teacher should present the subject matter with all the possible views on it. The findings of this study offer individual learners opportunity to live more purposefully in complex and rapidly changing conditions. This attribute obviously has implications for learners even beyond schools. It also has applicability for adults who especially are experiencing personal existential crisis in their lives. The educational implications drawn from existentialism enables an individual's to understand how their lives can be made more meaningful. For conducting this study, philosophical and historical methods were employed. The primary and secondary sources related to educational philosophy of existentialism were evaluated after detailed analysis. The general philosophical tools used for the study are induction, deduction, dialectical analysis and synthesis.
\end{abstract}

Key Words: Existentialism, pedagogy, classroom, crises, philosophy, personal meaning

\section{Introduction}

Existentialism is a modern philosophy emerging (existence-philosophy) from the 19th century, inspired by such thinkers as Kierkegaard and Nietzsche. Unlike traditional philosophy, which focuses on "objective" instances of truth, existentialism is concerned with the subjective, or personal, aspects of existence. The themes in the writings of Kierkegaard and Nietzsche were developed in Europe and a modern philosophical movement was born. Existentialism is linked prominently with such atheist thinkers as Sartre, Merleauponty and Camus, and religious thinkers like Marcel, Buber, Tillich, and Jaspers. Existentialism is not a systematic philosophy, with a hard and fast method of analysis, such as the "scientific method" rather, existentialism is a way of existing wherein we inquire into our existence - our Being is at issue and so we inquire into the things that have a deep and personal meaning for us! In the pursuit to understand our lives in connection with others, we begin to recognize common themes emerging, such as the meaning and import of freedom, responsibility, death, suffering, guilt, and the place of authentic values in human life.

Existentialism is one of the most important schools of philosophy, developed as a result of opposition to the methods of traditional western philosophy after the Second World War. In this philosophy beliefs opposite to the traditional philosophical thought are found. According to existentialism, the individuality of man is supreme and this 'individuality' is greater and more important than the existence of man, nation and the world. This philosophy recognizes the existence of individuality, opposing the notion of intelligence and nature. It is very much near to the individual life of man.

Existentialism represents a protest against the rationalism of traditional philosophy, against misleading notions of the bourgeois culture, and the dehumanizing values of industrial civilization. Since alienation, loneliness and self-estrangement constitute threats to human personality in the modern world, existential thought has viewed as its cardinal concerns a quest for subjective truth, a reaction against the 'negation of Being' and a perennial search for freedom. From the ancient Greek philosopher, Socrates, to the $20^{\text {th }}$ century French philosopher, Jean Paul Sartre, thinkers have dealt with this tragic sense of ontological reality - the human situation within a comic context.

The early $19^{\text {th }}$ century philosopher Soren Kierkegaard is regarded as the father of existentialism ${ }^{[1]}$. He maintained that the individual is solely responsible for giving his or her own life meaning and for living that life passionately and sincerely ${ }^{[2]}$, in spite of many existential obstacles and distractions including despair, angst, absurdity, alienation, and boredom ${ }^{[3]}$.

Subsequent existentialist philosophers retain the emphasis on the individual, but differ, in varying degrees, on how one achieves and what constitutes a fulfilling life, what obstacles must be overcome, and what external and internal factors are involved, including the potential consequences of the existence ${ }^{[4][5]}$ or nonexistence of $\operatorname{God}^{[6[1]]}$. Many existentialists have also regarded traditional systematic or academic philosophy, in 
both style and content, as too abstract and remote from concrete human experience ${ }^{[8][9]}$. Existentialism became fashionable in the post-World War years as a way to reassert the importance of human individuality and freedom ${ }^{[10]}$.

\section{Objectives of the study}

1 To study the philosophy of existentialism.

2 To study the educational implication of existentialism with special focus on class room pedagogy.

\section{Methodology}

Philosophical and historical methods have been used and apart from that both primary as well as secondary sources related to existentialism has been employed for the collection of data. Accordingly the data has been collected, scrutinized and critically analyzed for interpretation and for drawing conclusions.

\section{Existentialism and Education}

A central proposition of existentialism is that existence precedes essence, which means that the actual life of the individual is what constitutes, what could be called his or her "essence" instead of there being a predetermined essence that defines what it is to be a human. Thus, the human being - through their own consciousness- creates their own values and determines a meaning to their life. "Although it was Sartre who explicitly coined the phrase, similar notions can be found in the thought of many existentialist philosophers, from Mulla Sadra, to Kierkegaard, to Heidegger ${ }^{[11]}$."

As Sartre puts it in his Existentialism is a Humanism "Man first of all exists, encounters himself, surges up in the world - and defines himself afterwards." Of course, the more positive, therapeutic aspect of this is also implied: A person can choose to act in a different way, and to be a good person instead of a cruel person. Here it is also clear that since man can choose to be either cruel or good, he is, in fact, neither of these things essentially [12].

According to existentialists the way of good life does not go through social traditions, customs and social reform. The way of authentic life begins realizing himself by asserting his individuality and making his own choice instead of being stamped into the choices of collectivity. Hence students in the school should not be encouraged to criticize or to reform the social customs but they should choose their field of action and full responsibility should be borne by the students. Existentialists believe that if each student would realize full responsibility of his action, there would not be anti-social behavior in the society. They choose the path of individual improvement for social improvement. In existentialist view no choice is demonstrably better than any other because there is no any external standard to measure the value and validity. Man himself measures the validity of various choices; he is the judge of all the things. He should not look to history, culture or social institutions for any guidance in decision making ${ }^{[13]}$.

It is the responsibility of education that it should awaken in the student the existential awareness as a single subjectivity present in the world. He should be awakened to the full intensity of his own selfhood. He should realize that he has to choose his own way, for choosing he has full freedom and he is fully responsible for making his own destiny.

Existentialist prefers solution originating in the aesthetic, moral and emotional self ${ }^{[14]}$. Existentialism presents no formula for the reconstruction of society in which individual automatically will realize his identity and self-integrity. Existentialism emphasizes the importance of our understanding that how we face the situations and how we respond to them. We bear the responsibility of our choices and actions which can never be transferred ${ }^{[15]}$.

According to Kierkegaard, man is a synthesis of sensuality and the soul. Consciousness is something like a general background upon which a particular phenomenon looms up at any instant. The level of consciousness is created a new in the ethical stage and we can realize it in the decision making in contradictory situations. Man must be a high spirited being but we found mean-spiritedness which is due to the lack of infinite. He says that ethical meanness resulted in desperately narrow-mindedness and despairing narrowness consists in the lack of primitiveness. Kierkegaard observes that when a student is in confronting with the needs and demands of the out world; the inner conflicts, he should realize that he can get the answers to his problems within himself. When his consciousness comes close to finite facts than he can understand and realize them and makes any decision for action. This process never ends and he is always ahead of himself and in a process of 'becoming', a task which always remains not yet accomplished ${ }^{[16]}$. Student must cultivate self-reliance as a key character. He should not be provided any assistance from his school or society for choosing his aim, and nobody should fulfill his requirements, except himself. There should be no set of values and codes of conduct. Student must look within himself for the knowledge of ultimate values like good, truth and beauty. He says that knowledge should assist him in discovering his internal attitudes and his "degree of consciousness". He insists on the development of passions and emotions because these are the source of healthy spirit. Without passions 
the soul is something like that which has lost its possibility and potentiality. Hence, we come to the point that Kierkegaard's aims of education would be to arouse sentiments, feelings and emotions so that a student may realize his existence.

\section{Existentialism and Classroom}

Existential pedagogy applies to learners of all ages in all learning environments. However, existential pedagogy may have particular relevance for adult and lifelong learners. Adult and later life learners pursue learning opportunities for existential reasons. They may be attempting to overcome issues relating to selfactualization, achieve goals, overcome confusion, or define their identities. Adult learners are often intrinsically motivated, rather than extrinsically. Children tend to be more prone to be motivated extrinsically; however, philosophical or existential learning activities can be effective in the development of children, and children seem to enjoy such activities ${ }^{[17]}$.

Existential pedagogy embraces neither realism nor relativism, but rather, it supports sound methodologies for inquiry which are applied to any given situation. An existential worldview in which an honest and clear assessment of reality is present, will naturally be inclined to be skeptical, logical, and rigorous in its adherence to beliefs or alleged facts. Put another way, existentialism does not take leaps of faith about what is true or untrue. It relies on available evidence, and forms conclusions carefully. One conclusion that is often misinterpreted is that humans must treat each other with respect and promote freedom for all. While arguments that existentialism is an intrinsically selfish philosophy are true to an extent, it is not selfish to the point of dismissing or disrespecting others- contrarily, in order for selfish freedom to be enjoyed by an individual, it must also be universally available for all people. Therefore, an existential pedagogy would not reduce students to mere objects in a system, but would instead recognize the individuality and freedom of everyone. Even Howard Gardner "Believed that there may be an existential intelligence. He expressed difficulty articulating an existential intelligence due to lack of neurological evidence. Gardner was failing to see the forest through the trees. Existential motivation is the driving force behind all other intelligences. The challenge is for individuals to become aware of this inner force and harness it to influence decisions that positively develop personal meaning and identity. Education can empower an individual to be free to choose his or her own destiny, rather than being confined and defined by others or by circumstances ${ }^{[18] "}$.

An existential pedagogy promotes self-worth, and takes into account individual learners as opposed to a prescribed curriculum that disregards individuality. Independent learning is empowered by the use of technology. For example, an elementary student takes great pride and ownership of a PowerPoint presentation he creates about a topic he chooses, just as a graduate student takes pride and ownership of the online research he conducts to write a paper, create a website, or compose a presentation about a topic that is personally meaningful. Either student may have the additional freedom of earning credit online, which further promotes freedom and flexibility for independent self-directed learning.

David Walters argues for an existential learning theory in which the student-teacher relationship fosters self-worth and fulfillment of personal destiny. The instructor-student relationship should be one of mutual respect and a regard for one another as dynamic, human beings. Dismissing one another with preconceived schema about what an instructor or student is will be detrimental to both parties. Neither participant should objectify the other. They will be missing out on the deeper learning opportunities that emerge in honest, respectful relationships. As Walters writes, "Such relationships are continually committed to notions of personal worth and to one's destiny as an individual". Walters also refers to the existential belief that one should lead by example in what he refers to as a requisite "Giving of self" by teacher, mentor or therapist, that is, a form of pattern and example within mutual relating ${ }^{[19]}$,"

Existentialists say that every technique, every tool, every gesture is a way that opens upon the world. Reality has as many aspects as there are ways of manipulating it. They say that teacher should present the subject matter with all the possible views on it. He should read widely and set the subject matter before the class adequately, and genuine discussions should make students familiar with his own thinking and then ask students to evaluate his view against then own experience and knowledge. At this stage students should be completely free to set their view on the matter.

Play-way method has the great importance for existentialists, because the function of play is personal liberation - persona release. The desire to play corresponds with the desire 'to be' a certain type of person. The idea of play is thus united with the idea of 'art and science' to become a valuable means of self-expression. Existentialists believe that literature, the graphic arts, music and myth are far more than the source of truth than the sciences. Since truth for the existentialists derives from human subjectivity. They are strongly anti-scientific because for them science is cool, aloof and objective in its approach to nature and to man. In science and technology there is extreme specialization. Without integrating the information's collected by various sciences, we cannot reach to the worthy understanding of the little part of our physical nature. In spite of this when the scientific method have been applied for the study of human nature, the result would have been simply disastrous 
${ }^{[20]}$. They insist on the subject matter and method for investigation and teaching which appeal to feelings, emotional creativity and deeper meaning of life; and totally avoid the training and data based education. For them schools should cultivate insight fidelity, love and creative knowledge ${ }^{[21]}$.

Some educationists draw inferences about the role of the teacher from various principles of existentialist philosophy and found that their teaching style is very near to Socratic Method. In fact, his humanistic approach to philosophy and his insistence on man as a focus are the themes that find an important place in existentialism of $20^{\text {th }}$ century. Existentialist likes his way of teaching and a close relationship between teacher and student which Socrates established in his teaching. His teaching was personal, intimate, an I-though affair, in which knowledge and wisdom were achieved through the mutual interaction of two living beings. There were no classrooms, no administrators or principals. He came to close in open place with the people, who became his disciple when they were impressed by his views. His teaching style was interrogative in which he asked two types of questions- first, those whose answers he know; and second, those whose answers he does not know. At the second stage he was like an investigator who is probing for new truth ${ }^{[22]}$. His teaching was for the enlightenment of those with whom he was conversing. Through the process of questions and answers he pushed the issue until some acceptable conclusion was reached. But the metaphysical element in Socratic teaching differs markedly from the existentialist concept.

The method of pedagogy must allow for the student's development of her own unique possibilities, which is why the existentialists would reject a standardized curriculum and an authoritarian model for teaching. An "existential" curriculum would include a diverse content as well as an array of varied pedagogical methods, which would, importantly, include ample opportunities for peer initiated and peer-directed learning. Educators should plan lessons that embrace and incorporate aspects of the student's emotional and intellectual autobiography. However, it is not only the aspects of one's unique life story that matter, it is also important that students understand the major role that "history" and "heritage" play in shaping who we become - history's authentic role not only forges our past but as well contributes to the future enactment of our possibilities that we gather from our "heritage".

The instructional methods employed should not be resemble the out-dated authoritarian model, where the teacher is the "superior" possessor of knowledge and the student the "inferior," empty vessel waiting to be filled ${ }^{[23]}$. This is model for pedagogy views knowledge at an objective remove from the student, and demonstrates no concern for the place of the existential "lived world" in the curriculum as shared by both teacher and student. Knowledge, according to the existentialists does not reside at a remove from our "lived world" and in addition is constructive.

Thus existential pedagogy stressed the co-creative, co-responsive, and co-participatory aspects of education. This is not to indicate that the teacher allows the student to dictate each and every aspect of her education, for teachers need to be in command of the subject matter in order to first tailor it to fit the student needs. Teacher does not impart knowledge to students; he shows him how to acquire knowledge for himself. The most difficult task for educators is to learn how to let students learn.

\section{Conclusion}

Existentialism goes deeper by applying effective strategies as well as overarching reasons why learners learn. Not only is knowledge being created, but it is interdependent on a self-constructed sense of identity and awareness. Students who apply deep personal meanings with what they are doing and learning will do so more effectively. Students have the freedom to do things their own way. Existential pedagogy is relevant to modern times. It is a beneficial educational theory. Existential pedagogy illuminates the core of teaching and learning as personal pursuits to find meaning, define identities, and live authentically and freely. Existential pedagogy applies to learners of all ages in all learning environments. However, existential pedagogy may have particular relevance for adult and lifelong learners. Adult and later life learners pursue learning opportunities for existential reasons. They may be attempting to overcome issues relating to self-actualization, achieve goals, overcome confusion, or define their identities.

\section{References}

[1] Marino, G. (2004). Basic Writings of Existentialism, p. ix, 3.Modern Library, USA.

[2] Lowrie, W. (1968). Kierkegaard's Attack Upon Christendon, p. 37-40. Princeton: Princeton University Press.

[3] Corrigan, J. (2008). Oxford Hand Book of Religion and Emotion, p. 387-388 Oxford University Press.

[4] Livingstone James et al. (2006). Modern Christian Thought: The Twentieth Century, First Forester Press, Minneapolis, Minnesota. Chapter 5

[5] Martin, C. (2006). Religious Existentialism in Companion to Phenomenology and Existentialism, p. 188-205, Blackwell Publishing Company, Cambridge.

[6] Robert, S. (1974). Existentialism, p. 102. McGraw-Hill, Company.

[7] Cooper, D. (1999). Existentialism: A Reconstruction, p.8 Basil,Blackwell, Combridge.

[8] Ernst, B, (1962). Introduction to Modern Existentialism, p.5.Grove press, New York.

[9] Walter, K. (1956). Existentialism: From Dostoevsky to Sartre, p. 1. World Publishing Company, New York.

[10] Guignon. C and Derk, P. (2001). Existentialism: Basic Writings, p. xiii. Hackett Publishing Company. Inc. Cambridge. 
[11] Malik, G. and Rukhsana, A. (2012). Existentialism and Present Educational Scenario, Researcher, Vol. 4, No.10, p.95. Mars land Press, New York.

[12] Baird, F. and Walter K. (2008). From Plato to Derrida, Upper Saddle River, Pearson Prentice Hall, New Jersey.

[13] Kusum, L. (2005). Existentialism in Education: Philosophical and Sociological Analysis, p.105.Sanjay Prakashan, New Delhi.

[14] Ibid,106

[15] Ibid.

[16] Ibid.

[17] Leif, A. (2010). Existential Pedagogy: Personal Meaning and Technology in Education, edtech2.boisestate.edu/nelson/existential/tech pedagogy. Boise State University.

[18] Ibid.

[19] David, W. (2008). Existential Being as Transformative Learning, Pastoral Care in Education: An International Journal of Personal, Social and emotional Development, Vol. 26, No. 2, p.111-118. Taylor and Francis, Rutledge, London.

[20] Max, W. ( 1975). Philosophies of Education: An Introduction, p. 336. Sterling Publication Pvt. Ltd. New Delhi.

[21] Kneller, G. (1958). Existentialism and Education, p. 137. John Willey and Sons Inc., New york.

[22] Morris. V. (1990). Existentialism in Education: What it Means ( ${ }^{\text {nd }}$ Edt.), p.136. Harper and Row Publishers, New York.

[23] James, M. (2012). Existentialism, Phenomenology, and Education, Philosophy, p. 4. Scholarship, paper, 30. (http://dc.cod.edu/philosophypub/30) 